\title{
Geachte lezer,
}

Hoewel dit jaar enigszins overschaduwd is door COVID-19, vieren wij in 2021 een mijlpaal: namelijk de $100^{\mathrm{e}}$ verjaardag van medicinale insuline!

Het verhaal begint op 17 mei 1921 in Toronto (Canada), toen Frederick Banting, een arts, en Charles Best, een geneeskundestudent, begonnen met hun zomers onderzoeksproject in het laboratorium van John James Rickard Macleod. In juli van dat jaar - ruim 2 maanden later - slaagden zij erin insuline uit de alvleesklieren van honden te extraheren en te isoleren. Vervolgens injecteerden ze deze oplossing in een hond waarvan de alvleesklier was verwijderd. Verbazingwekkend genoeg waren zij in staat om de hond - genaamd Marjorie - in leven te houden met hun pancreasextract. De resultaten waren bemoedigend, maar zij bleven worstelen om stabiele en voldoende hoeveelheden van het pancreasextract te produceren. Eind 1921 nodigden zij James Collip, een biochemicus, uit om zich bij hun team aan te sluiten. Uiteindelijk waren zij in staat om een pancreasextract van voldoende zuiverheid en potentie voor menselijk gebruik te produceren. In 1922 werd door Banting de eerste diabetespatiënt, Leonard Thompson, behandeld met externe insuline. Een jaar later, in 1923, ontvingen Banting en Macleod de Nobelprijs voor Fysiologie \& Geneeskunde. Al snel werd duidelijk dat de tot dan toe dodelijke ziekte diabetes behandeld kon worden door de toediening van insuline. Uiteraard ontstond de behoefte om kunstmatig insuline te produceren. De eerste bronnen voor medicinale insuline waren koeien, paarden en varkens. In de jaren 80 van de vorige eeuw werd dit vrijwel volledig vervangen door synthetische humane insuline. In de jaren daarna ontwikkelde men insuline-analoga, die door de modificatie van humane insuline juist sneller of langzamer worden afgegeven aan de bloedbaan. Het jubileumjaar van insuline - 2021 - wordt gedomineerd door kosten, de verschijning van insuline biosimilars en het preferentiebeleid door zorgverzekeraars. Dit betekent dat de verzekeraar een voorkeur heeft voor een bepaald medicijn als er meerdere van die medicijnen op de markt zijn. In het huidige nummer kunt u lezen over de zorgen die ontstaan zijn naar aanleiding van dit preferentiebeleid. Verder besteden we in dit nummer aandacht voor de diabetische voet en de herziening van de NDF Voedingsrichtlijn diabetes, met daarbij aandacht voor persoonsgerichte zorg.

Me dunkt weer voldoende garantie voor het nodige leesplezier.

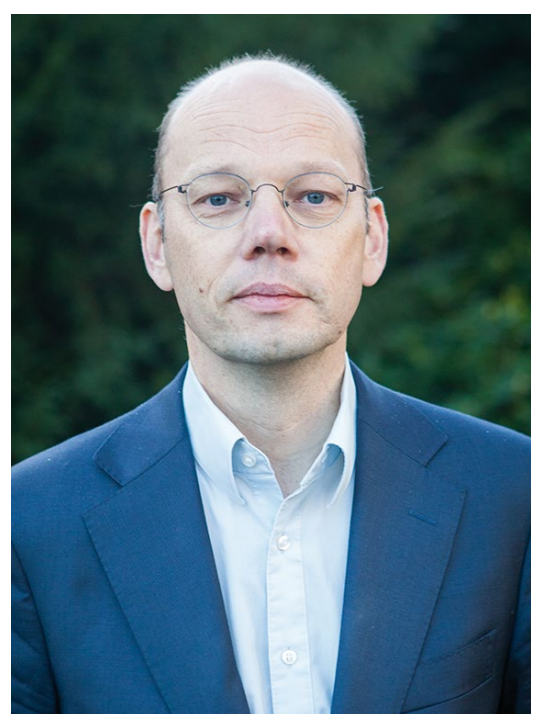

Erik Serné, hoofdredacteur redactieNTD@bsl.n| 